\title{
Definitions of metrological concepts are lighthouses
}

\author{
Paul De Bièvre
}

Published online: 4 November 2010

(C) Springer-Verlag 2010

Recently, I was attending a meeting of an IUPAC body where, once in a while, several concept definitions of the new International Vocabulary of Metrology (VIM) [1] helped to clarify the intercontinental communication of the people present. Intercontinental indeed, as Japanese and Russian attendants participated next to European delegates. Again, it had gradually dawned on the participants that we need to understand what is covered by a term before we can validly translate the term from one language into another one. In other words, we must first define the concept which we have in mind and make sure we understand this definition in the same way, before we use the term covering this concept in the language we happen to use in any given discussion.

The kind hosts of the meeting treated the people present on a brief excursion to their Western neighbour: the Atlantic Ocean with its marvellous surf, a grandiose picture of nature. Next to the entrance of a small fishermen's port stood a solid lighthouse the lights of which had for centuries be warning boats for imminent disaster, but which also had been guiding into a safe harbour.

Suddenly the analogy struck me: short and clear definitions of the concepts we are handling in our minds, act like light houses. They are beacons in the wild sea of disorderly thinking and communication in chemical measurement. Their light shines, thus making visible the disordered scenery of words, terms, and sentences in both our oral (in meetings) and written (in our professional literature) communication.

P. De Bièvre $(\bowtie)$

Kasterlee, Belgium

e-mail: paul.de.bievre@skynet.be
But also their light shines to guide our communication along clear routes to the quiet harbour of transparent understanding. Together with other signs, they indicate the safe route to that harbour.

In very early ages, mankind were looking for and created beacons in a seemingly disordered environment. We could do the same in our communication by creating ordered routes aligned with shining beacons: the very purpose of a VIM. Not doing so may lead to non-understanding, possibly to disasters, in communication in the same way as not having lighthouses may lead to shipping disasters.

Definitions of metrological concepts are lighthouses which are clarifying our communication about results of chemical measurements.

As definitions of metrological concepts should be ...

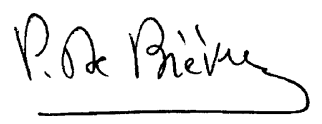

Paul De Bièvre

Editor-in-Chief

By the way, looking for justification of Metrology in Chemistry?

An EU ban on the import of Tilapa fish from Victoria Lake countries caused a loss of USD $10 \cdot 10^{6}$ as well as 150000 jobs.

quoted by $\mathrm{R}$ Kaarls at the 5th Brasilian Congress of Metrology, 09 November 2009 in Salvador (Bahia) Brasil.

Would it not be useful that sufficient Education \& Training in metrological principles be provided to local laboratories so as to avoid that Victoria Lake countries be prevented from exporting to the EU? 
Reference

1. BIPM, IEC, IFCC, ILAC, IUPAC, IUPAP, ISO, OIML (2008) The

international vocabulary of metrology - basic and general concepts and associated terms

http://www.bipm.org/vim
(VIM), 3 edn. JCGM 200.

\section{.}

